ROCZNIKI HUMANISTYYCZNE

Tom LXVII, zeszyt 6 - 2019

DOI: http://dx.doi.org/10.18290/rh.2019.67.6-5

\title{
WOKÓŁ PODSTAWOWYCH ZAGADNIEŃ METODOLOGICZNYCH I PROPOZYCJI BADAWCZYCH W ZAKRESIE ETYKI KOMUNIKACJI JĘZYKOWEJ
}

\section{UWAGI WSTĘPNE}

Współczesna kultura opiera się na komunikacji społecznej, w coraz większym stopniu kształtowana jest przez technologie komunikacyjne. Za istotne czynniki funkcjonowania człowieka jako podmiotu kultury uznaje się racjonalność komunikacyjna oraz etyke komunikacyjna. Hołdują tej tezie m.in. etnolingwistyka Herberta Paula Grice'a (teoria implikatur konwersacyjnych), teoria dziatania komunikacyjnego Jürgena Habermasa, aksjologia w ujęciu Seweryna Dziamskiego (Grice 1980, 96; Habermas 1972; Habermas 1986, Habermas 1999; Habermas 2002; McCarthy 1978, 25-27; Dziamski 1997; Dziamski 2002, 59-60; Dudziak 2012, 57-58). W takim kontekście okazuje się w pełni uzasadnione rozwijanie badań nad etyka komunikacji językowej. Staje się to istotnym zagadnieniem także ze względu na niepokojącą skalę szerzenia się mowy nienawiści $i^{1} \mathrm{w}$ komunikowaniu. Ponadto zdarza się, że

Dr hab. ARKADIUSZ DUDZIAK - adiunkt Zakładu Komunikacji Społecznej, Wydział Humanistyczny Uniwersytetu Warmińsko-Mazurskiego w Olsztynie; adres do korespondencji: ul. Kurta Obitza 1, 10-725 Olsztyn; e-mail: arkadiuszdudziak@interia.pl

${ }^{1}$ Zjawisko to jest rozumiane jako synonim angielskiego terminu hate speech. Dotyczy negatywnych, motywowanych uprzedzeniami, emocjonalnych wypowiedzi, wrogo oceniających jakieś jednostki lub grupy, zachęcających do przemocy, usprawiedliwiających agresję. Za mowę nienawiści uznaje się wypowiedzi ,lżące, oskarżające, wyszydzające i poniżające grupy i jednostki z powodów po części od nich niezależnych - takich, jak: przynależność rasowa, etniczna, religijna, a także płeć, preferencje seksualne" (ŁODZIŃSKI 2003; na ten temat por. KowALSKI / TULLI 2003; WEBER 2009. Na temat słownictwa dyskredytującego o charakterze inwektyw - zob. CegieŁa / KuCiński / PolKowska / StęPIEŃ 2014, 58-65). 
z centrum zainteresowania opinii publicznej znika perspektywa etyki nawet w sytuacjach zdawałoby się bezwzględnie wymagających oceny etycznej. Tak się stało w przypadku tzw. afery podsłuchowej w związku z opublikowaniem na łamach „Wprost” w 2014 roku rozmów prominentnych osób publicznych. W owym czasie w medialnych dyskusjach na ów temat zupełnie pominięto refleksje etyczne i moralne oceny zjawiska, co wskazuje na kryzys wartości w polskiej debacie publicznej (Dudziak 2015, 297-313).

Prezentowane refleksje są inspirowane pracami polskich etyków: Henryka Elzenberga, Stanisława Kamińskiego, Andrzeja Grzegorczyka, Józefa Jaronia, a także wybranymi koncepcjami badaczy etyki komunikowania. Celem artykułu jest próba zainicjowania dyskusji dotyczącej tego, w jaki sposób badać etykę komunikacji językowej:

- jak ją definiować?

- jaki ustalić zakres i przedmiot badań, jakie wyznaczyć obiekty badawcze?

- co uznać za cel badawczy?

- jakimi metodami prowadzić badania?

\section{PRÓBA DEFINICJI}

W prezentowanym artykule definiuje się etykę komunikacji językowej jako zestaw normatywnych zaleceń (wzorców) dotyczących: a) słusznego moralnie / moralnie preferowanego postępowania komunikacyjnego w wymiarze zarówno postaw podmiotów komunikujących, jak i moralnej stosowności generowanych komunikatów (czyli zgodności z typologią wartości moralnych, z moralnym sposobem wartościowania), językowych tekstów bezpośrednich lub generowanych za pośrednictwem technologii medialnych; b) adekwatnych, moralnie poprawnych reakcji odbiorczych na owe komunikaty - z uwzględnieniem dobra współistnienia społecznego (nawiązywania relacji, inicjowania sytuacji dialogicznych w celu przekazywania myśli, idei, wartości etc. oraz podejmowania działań), tj. należytego wzajemnego traktowania się uczestników aktów komunikowania, uznania wartości godności ludzkiej i wzajemnego szacunku. Owe zalecenia wynikają z przyjętego w danym środowisku społecznym (przynależnym do danego kręgu kulturowego) określonego systemu wartości moralnych, norm i ocen moralnych (Jaroń 1995,11).

Jako dyscyplina etyka komunikacji językowej opiera się na aksjologii i dotyczy tego, w jaki sposób moralnie komunikować, mając na względzie pojęcie dobra w sensie deontologicznym. W nawiązaniu do etyki Henryka Elzenberga $\mathrm{w}$ niniejszym ujęciu traktuje się etykę komunikacji językowej 
w kategoriach doradczych, nie imperatywnych (doradzania, lecz nie nakazywania). Preferuje się moralne postawy komunikowania oparte na swobodzie wyboru wartości, a nie na arbitralnie narzucanym obowiązku moralnym. Ufa się w zdolność i skłonność podmiotów komunikujących do bycia wartościowymi ludźmi: czyniącymi dobro z osobistej potrzeby, dążącymi do aksjologicznego samookreślenia, wyrabiającymi w sobie cechy wartościotwórcze (Elzenberg 2005, 38-39; Elzenberg 2001, 184-185; Hostyński 1991, 109-157; Tyburski 2006, 107-108).

\section{KWESTIE METODOLOGICZNE ETYKI KOMUNIKACJI}

Etyka komunikacji / etyka komunikowania jako twór pojęciowy zawiera składową nazewniczą ,etyka”. Należałoby zatem uznać etykę komunikacji za swoistą odmianę etyki, czyli dostosowaną do procesów komunikacji językowej teorię moralności, tj. określony system norm moralnych, zasad moralności oraz społecznych ocen moralnych. W takim rozumieniu etyki komunikacji pojawiają się dwie kwestie charakterystyczne dla metodologii badań nad etyką na gruncie filozofii: a) jaki cel poznawczy wiąże się z tym komunikacyjnym typem etyki? b) jaką funkcję pełni ta etyka w praktyce komunikacji językowej? (na temat metodologicznych typów etyki zob. Kamiński, 1989, 307-319). W związku z tym pojawiają się do rozstrzygnięcia następujące zagadnienia:

- czy uzasadnione jest stosowanie jednej tylko (ogólnej) nazwy dla etyki komunikowania, czy może należałoby wyróżnić osobne twory terminologiczne w zależności od rodzajów wiedzy o moralności komunikacji społecznej czy roli odgrywanej w rozwiązywaniu moralnych konfliktów komunikowania?

- czy zbiory norm etycznych komunikowania, moralne kodeksy komunikacji oraz moralistykę (moralizatorskie próby skłaniania podmiotów komunikujących do akceptacji norm i wartości moralnych poprzez propagowanie zaleceń i wydawanie ocen, formułowanie sądów moralnych) należy również zaliczyć do etyki komunikacji językowej rozumianej naukowo jako dziedzina badań, czy też wyłączyć z dociekań objętych rygorem metodologii?

- w jaki sposób uprawiać etykę komunikacji językowej zgodnie z metodologiczna tradycja weberowska w sposób racjonalny, naukowo neutralny, obiektywny? (Weber 2004, 195-242)

- a może jednak przyznać, wbrew postulatom Webera, że powinnością nauki jest też formułowanie, uzasadnianie i upowszechnianie rzetelnych sądów wartościujących, należycie ukonstytuowanych na podstawie ugruntowa- 
nej teorii prawdy wraz z umiejscowieniem tejże wartości etyczno-poznawczej w hierarchii wartości i praktyce moralnej? (Ostasz 2009, 150-151).

Możliwe wydaje się przyjęcie terminu metaetyka komunikacji (ogólna wiedza o rozwiązywaniu moralnych problemów komunikowania), pojmowana jako nauka o przedmiocie badań etyki komunikacji językowej, jej obiektach badawczych, celach, metodach, jej historii oraz jej odmianach typologicznych. W etyce komunikacji (jako nauce) należałoby wyodrębnić przedmiot, cel(e) badań oraz metodę badawczą (metody uprawiania). Celami badań etyki komunikacji językowej będą: opisywanie, wyjaśnianie oraz przekształcanie postaw moralnych, co dawałoby odpowiednio trzy odmiany etyki: opisową, wyjaśniającą oraz pedagogiczną (wychowawczą). Za przedmiot etyki komunikacji językowej można uznać fenomen moralności komunikacyjnej. Polega on na dokonywaniu w świadomości podmiotu komunikującego wewnętrznego aktu wyboru dobra moralnego lub zła moralnego, czyli na dokonywaniu w akcie komunikowania świadomego i dobrowolnego wyboru pomiędzy tym, co w danym kręgu społeczno-kulturowym uznaje się za wartościowe i godziwe (ewentualnie również tego, co należne osobie, powinnościowe do afirmowania ze względu na godność osobową) albo na negacji tego, co się jawi jako dodatnio waloryzowane moralnie w danym kręgu kulturowym (na temat fenomenu moralności w etyce ogólnej - zob. Kamiński 1989, 309).

Na temat różnicy w doświadczaniu wartości i powinności, jak również w rozumieniu oceny i normy moralnej Stanisław Kamiński skonstatował:

uznanie [...] wartości pociąga za sobą przyjęcie powinności, zaś asercja powinności implikuje akceptację wartości. Doświadczenie wartości ma charakter imperatywny, aby czynić dobrze, a unikać zła. Natomiast doświadczenie powinności zawiera w sobie afirmację wartości osoby. Analogiczna sytuacja zachodzi między oceną i normą moralną. W zdaniach tych zawiera się taka sama informacja, a rozmaite są formy i stopnie asercji poszczególnych momentów treściowych oraz rekomendacji. Można to zilustrować na przykładzie: $\mathrm{x}$ jest moralnie dobre dla y (przeto $\mathrm{x}$ moralnie obowiązuje $\mathrm{y} \mathrm{w}$ realizacji) $=\mathrm{y}$ jest moralnie zobowiązany działać x (bo x dla y jest moralnie dobre) (Kamiński 1989, 309).

W etyce komunikacji językowej o proweniencji personalistycznej pod terminem moralność będzie rozumiane międzyosobowe zachowanie się zgodne (dobro moralne) albo niezgodne (zło moralne) z godnością osoby.

Do podstawowych zadań etyki komunikacji językowej można zaliczyć:

- gromadzenie, analizowanie i interpretowanie zasad etycznych, rekomendowanych w dziejach komunikacji; 
- opracowywanie i postulowanie pożądanych moralnych wartości komunikacyjnych, norm i ocen dotyczących moralnego wymiaru komunikatów;

- propagowanie moralnie słusznych postaw uczestników aktów komunikowania;

Kategoriami badawczymi (obiektami badań) w etyce komunikacji językowej mogą być następujące kategorie:

- postawa moralna podmiotów komunikujących (uczestników aktu komunikowania);

- podmioty postawy moralnej i postępowania moralnego (dokonujące w akcie komunikowania moralnego wyboru dobra lub zła);

- wzory postaw moralnych i postępowania moralnego w komunikowaniu;

- świadomość moralna, sumienie uczestników aktów komunikacji;

- motywy i sankcje moralnych postaw w komunikowaniu;

- sądy zawierające oceny moralne danych komunikatów;

- sądy na temat norm wyrażających powinności moralne;

- sądy na temat wartości moralnych oraz moralne wartościowania: podmiotów komunikujących, aktów komunikacji, samych komunikatów / generowanych tekstów.

Etyka komunikowania językowego może się sprowadzać do opisów systemów moralności komunikacyjnej, obiegowych kodeksów moralnych określonych środowisk i podmiotów komunikujących, oceny i wartościowania obyczajów związanych z komunikowaniem w danym środowisku społeczno-kulturowym. Zgodnie $\mathrm{z}$ historycznymi konwencjami uprawiania etyki na gruncie filozoficznym etyka komunikacji językowej może przyjmować ujęcie aksjologiczne (badanie / opisywanie samej moralnej wartości w komunikowaniu) bądź ujęcie deontyczne (badanie / opisywanie samej powinności moralnej uczestników aktu komunikacji). Refleksje z zakresu etyki komunikacji będa zapewne dotyczyły wartości i powinności, ocen i norm oraz zasad moralnych jako kryteriów dobra i zła w komunikowaniu. Etyka komunikacji często będzie dotyczyć ocen postępowań komunikacyjnych jako moralnie dobrych lub złych, tj. powinnych albo niepowinnych (Kamiński 1989, 310-311). Potencjalnie na gruncie humanistycznej etyki komunikowania (etologii) mogą zostać wyodrębnione trzy nurty badawcze: z zakresu psychologii moralności komunikacji, z zakresu socjologii moralności komunikacji, z zakresu historii moralności komunikacji. Jak zauważył Stanisław Kamiński:

psychologia moralności bada mechanizmy i struktury oceniania moralnego oraz uwarunkowania psychiczne moralnego zachowania się. [...] Zajmuje się także sumieniem, autonomią i heteronomią moralności, wolnością i odpowiedzialnością 
oraz funkcjonowaniem sankcji moralnych. Socjologia moralności szuka sił społecznych, które kształtują aktywność moralną i modę na określone ideały i poglądy moralne oraz bada życie moralne jako wzajemne uwarunkowanie osobowości i społeczności (np. jak i jakie poglądy na moralność wpływają na społeczeństwo i odwrotnie) [...]. Historia moralności traktuje o rozwoju życia moralnego (zarówno samego postępowania, jak i wydawanych opinii o moralności oraz dziejach funkcjonowania systemów moralności) w jego powiązaniu z innymi dziedzinami kultury [...]. Niejednokrotnie zbliża się do historiozoficznych refleksji nad przemianami w dziedzinie całej kultury moralnej. Metaetyka nie zajmuje się wprost pierwotnymi fenomenami moralności. Stara się natomiast rozwiązać zagadnienia moralne, badając i charakteryzując wypowiedzi dotyczące moralności czy przede wszystkim istniejące systemy moralności. [...] Należy zaznaczyć, że sądy moralne są [...] samym obiektem badań. Aspektem zaś systemu moralnego, którym głównie interesuje się metaetyk, jest znaczeniowa strona wyrażeń moralnych oraz uzasadnialność sądów (ocen lub norm) moralnych i ich kwalifikacja pod względem wartości logicznej (Kamiński 1989, 311-312).

Z uwagi na potencjalny cel badań można wyodrębnić dwie podstawowe odmiany etyki komunikowania językowego:

- opisowo-wyjaśniajaca etykę komunikacji - dotyczyłaby ona opisu i interpretacji zaistniałych faktów z zakresu moralności interakcji komunikacyjnych;

- normatywno-oceniajaca etykę komunikacji - polegałaby ona na: rozwijaniu wiedzy o moralności komunikacyjnej; sugerowaniu, co jest moralnie dobre i dlaczego jest moralnie dobre; wyjaśnianiu, w jaki sposób i dlaczego podmioty komunikujące zobowiązane są postępować w imię dobra moralnego; uzasadnianiu uniwersalnych norm moralnych i ocen; uprawianiu moralizatorstwa; propagowaniu moralnych wzorców komunikowania społecznego.

Józef Jaroń zaliczył do etyki opisowej metaetykę (badania nad: aparatem pojęciowym i językiem etyki; sądami etycznymi, zagadnieniami prawdy, wolności i odpowiedzialności moralnej, oceną etyczną; istotą sumienia), a także historię moralności, socjologie moralności oraz psychologię moralności. $\mathrm{W}$ tej odmianie etyki dokonuje się opisu, analizy i wyjaśniania pochodzenia moralności, jej genezy i historii oraz istoty i funkcji. Celem badawczym etyki opisowej są odpowiedzi na pytania:

- co uważa się za moralne lub niemoralne?

- dlaczego uważa się coś za moralne względnie niemoralne?

Etyka normatywna dotyczy z kolei powinności moralnych oraz wartościowań. Pytania badawcze etyki normatywnej to:

- co należy uważać (co powinno się uznawać) za dobro moralne?

- jak należy postępować stosownie do wymogów moralności? (Jaroń 1995, 38-39). 
Etyka komunikacji językowej może zmierzać m.in. do:

- porządkowania faktów moralnych występujących w danych sytuacjach komunikacyjnych i aktach komunikacji;

- uprawomocnienia wartości moralnych i powinności komunikacyjnych z nich wynikających;

- uzasadniania zasad realizacji wartości i powinności moralnych w komunikowaniu;

- badania języka moralności;

- analizowania wypowiedzi języka potocznego w aspekcie logiki moralności;

- charakteryzowania wzorców moralnie dobrego zachowania komunikacyjnego (Kamiński 1989, 313-314).

Etyka komunikacyjna może przybierać funkcję etologii - wyjaśniać zdarzenia kulturowe (obyczaje komunikacyjne, głoszone poglądy na moralność, obserwowalne zachowania podmiotów komunikacji) za pomocą prawidłowości życia moralnego i jego relacji do innych dziedzin kultury. Etyka komunikacji językowej może mieć również charakter metafizyczny - tłumaczyć wartości i powinności moralne osobową naturą człowieka i jego relacyjnym stosunkiem do innych osób (Kamiński 1989, 314-315).

Inspirujący teoretycznie dla konstytuowania etyki komunikacji językowej może być dorobek lubelskiej szkoły „wyjaśniającej etyki wartościująco-normatywnej" Stanisława Kamińskiego i Tadeusza Stycznia (Styczeń 1984, 3973; Kamiński 1989, 307-319, 321-330, 331-340).

Antropologiczna wyjątkowość sprowadza się do skłonności i umiejętności odkrywania wartości wyższych (prawdy, dobra, sprawiedliwości) oraz do skomplikowanego życia emocjonalnego w relacjach społecznych, przejawiającego się m.in. we wrażliwości; w doświadczaniu współczucia, bezinteresowności, wrażliwości na cudze cierpienie, wrażliwości na dobroć; w wyobrażaniu siebie w sytuacji drugiego osobnika; w gotowości bezinteresownego ulżenia drugiemu; w umiejętności delektowania się przeżyciami moralnymi (Grzegorczyk 1989, 23-25).

W zakresie uprawiania moralnej historii komunikacji językowej rysuje się perspektywa współczesnych weryfikacji hipotez badawczych, które na gruncie etyki postawił niegdyś Andrzej Grzegorczyk. Badacz najwcześniejszych dziejów kształtowania się postaw etycznych i wartości moralnych skonstatował:

bez zrozumienia potrzeb drugiego człowieka oraz współczucia i minimalnej dobroci współdziałanie ludzkie byłoby całkowicie niemożliwe i gatunek ludzki by się nie uchował. Uznawanie moralnych wartości miało więc - jak można przy- 
puszczać od początku swoje miejsce w historii. Jednakże wartości te nie sa w człowieku ugruntowane w sposób trwały. Ich odczucie daje o sobie znać tylko chwilowo. W innych, dość częstych momentach przeważają postawy negatywne: złość, zazdrość, zawiść, zemsta. Dość wcześnie ujawniającym się poważnym problemem duchowości ludzkiej było ich ograniczenie, a stymulowanie postaw pozytywnych (Grzegorczyk 1989, 35).

Zdaniem tego autora rozwój mowy wpłynął w dziejach ludzkości na rozwój moralno-religijny naszego gatunku, utrwalając w kulturze tendencje metafizyczne, transcendentne:

przed powstaniem mowy człowiek wyrażał swoje postawy moralne, i zapewne metafizyczne, zachowaniem i gestem. Współczucie okazywane czynem poprzedzało mowę. Również wyrazem radości z osiagnięć, jak i bólu z powodu utraty ludzi bliskich musiało być zachowanie i być może obyczaje ruchowe poprzedzające mowę. Mowa jednak pomogła $w$ rozwinięciu tych przeżyć. Powstała duża dziedzina haseł wokalnych moralno-religijnych, które wiązały się z pewnymi sytuacjami ważnymi dla życia duchowego, jak: wina, przebaczenie, radość, cierpienie, przemijanie, śmierć. Operowanie pojęciami moralno-religijnymi umożliwiło lepsze zauważenie tych zjawisk i samoświadomość ludzkich zachowań. Poza tym w języku uzewnętrzniło się charakterystyczne dla wszystkich kultur odesłanie ludzkiego losu do rzeczywistości nie znanej, przekraczającej nasz byt. To przeżycie transcendencji mogło mieć swój odpowiednik w kulturze przedsymbolicznej w postaci gestów i wydawanych dźwięków w momencie przeżywania wielkich zjawisk przyrody. Język symboliczny pozwolił lepiej utrwalić postawy transcendentne (Grzegorczyk 1989, 37).

Obiecujące poznawczo wydaje się skupienie uwagi analitycznej oraz interpretacyjnej na takich antropologicznych właściwościach - mających wpływ na etykę komunikowania językowego - jak: poznawanie głębokich związków między rzeczami; odkrywanie dalekich przyczyn i niewidocznych zależności; samoświadomość w sensie widzenia siebie, własnych wewnętrznych doznań jako bodźców osobistych zachowań i działań wywołujących dalsze skutki; wyczucie wartości, szczególnie etycznych (jak np. życzliwość, szacunek, sprawiedliwość); sprawdzanie przyczynowości, analizowanie własnego sprawstwa; sprawdzanie własnej niezależności (wolności); intencjonalne komunikowanie się, nastawione na osiągnięcie efektu perswazyjnego; sprawdzanie sensu i znaczenia mowy; ideacja (zdolność tworzenia idei i manipulowania nimi), jak również regulacja wolicjonalna, wykonywanie postanowień i przyrzeczeń, umiejętność przymuszania się do systematycznego wysiłku w określonym celu (Grzegorczyk 1989, 52-56, 67). 
Interesującym aspektem etyki komunikowania językowego byłoby zbadanie interakcyjnych aktywności komunikacyjnych dzieci (zarówno werbalnych, jak i pozawerbalnych) względem dorosłych w zakresie poznawania przez najmłodszych reakcji otoczenia społecznego na zachowania i działania moralnie destrukcyjne, postawy sprzeciwu względem woli dorosłych, inne próby wypróbowywania moralnego zakresu dziecięcej niezależności, wolności (Grzegorczyk 1989, 54).

Godna interdyscyplinarnej weryfikacji (na podstawie współczesnych zdobyczy nauk humanistycznych i społecznych) wydaje się teza Grzegorczyka z zakresu historii komunikacji językowej na temat genezy mowy i społeczno-kulturowych mechanizmów jej rozwoju:

można mniemać, że z zauważenia swojego głosu jako przyczyny cudzych zachowań narodziło się porozumiewanie za pomocą dźwięków. Prawdopodobnie pierwsze języki kojarzyły tylko całość wypowiedzi z całością sytuacji, rzeczy lub zachowania. Potem dopiero złożoność sytuacji, której musiała odpowiadać złożoność wypowiedzi, spowodowała powstanie zdań. A fleksja powstała jeszcze później. W tworzeniu struktury języka udział miał czynnik ideacji [...]. Dzisiaj operowania językiem uczymy się poprzez naśladownictwo. Dzieci uczą się naśladować bezpośrednio, a dorośli poprzez stosowanie reguł. Ale jest to stosowanie języka na podstawie istniejącego dziedzictwa kulturowego. Natomiast początki kultury mowy musiały się opierać na zauważeniu skutku oddziaływania dźwiękowego i świadomym wywoływaniu takiego skutku. Na tej drodze jeszcze obecnie dokonuje się wzbogacenie repertuaru dźwięku i gestu w pewnych grupach ludzkich. Obejmuje ono na przykład pewne okrzyki rodzinne, grupowe, gesty porozumiewawcze, półsłówka i podobne im zachowania częściowo spontanicznie ekspresywne, częściowo symboliczne (Grzegorczyk 1989, 54-55).

Tematem refleksji etyków komunikacji językowej może być wpływ ideacji na postawy komunikacyjne, intencje komunikowania, jak również rola manipulowania wyobrażeniowo-pojęciowego w przedsięwzięciach twórczych, odkryciach poznawczych, a także wywoływaniu złudzeń, dokonywaniu oszustw, fałszowaniu stanu rzeczy (Grzegorczyk 1989, 56-57, 62-63).

Inspirującym zagadnieniem w etyce komunikacji językowej jawi się opisanie mechanizmów świadomego i nieświadomego oszustwa, instynktownego maskowania intencji komunikacyjnych (w perspektywie nagrody lub kary), moralnej odpowiedzialności za oszustwa nieświadome (Grzegorczyk 1989, 59).

Pewną ugruntowaną pozycję w tradycji rozważań etycznych o komunikowaniu językowym mają badania nad zależnościami pomiędzy etyką a retoryką (Lichański 2009, 9-20; Jaśtal 2012, 73-89; Badyda 2012, 175). Na uwagę zasługuje zwłaszcza teza Jacka Jaśtala o inspirującej roli dziedzictwa retorycznego do 
współczesnych badań etycznych, jak również przekonanie autora o tym, że istota wartościowania opinii (poprzez odnoszenie ich do kategorii prawdy) jest umocowywanie tychże w poprawnym rozumowaniu w celu weryfikowania rzetelnej wiedzy i jej pozoru (Jaśtal 2012, 75). Jak słusznie konstatuje badacz:

zasadniczą kwestią dla rozważań na temat związków etyki i retoryki staje się pytanie, jak przejść od phronesis zdefiniowanej za pomoca środków pozaretorycznych do wskazania, co jest w sztuce oratorskiej poprawne i dozwolone (Jaśtal 2012, 80).

Godnym bardziej wnikliwych eksploracji jawi się pytanie: „czy możliwy jest etyczny sposób uprawnia retoryki przez ludzi, którzy nie są jeszcze w pełni etycznymi?" (Jaśtal 2012, 84). Inną kwestią etyki komunikowania staje się rozpatrywanie retoryki w aspekcie sztuki mądrego życia (Jaśtal 2012, 89).

Osobne zagadnienie do eksploracji w etyce komunikowania językowego stanowi klasyfikowanie tego, z jakimi postawami moralnymi wiąże się stosowanie określonej tonacji retorycznej przez nadawców, jak również badanie zjawiska odwrotnego, czyli tego, jakie postawy moralne odbiorów są kształtowane w efekcie perswazyjnym, wywołanym danymi komunikatami retorycznymi. Szerszym problemem etyki komunikowania jawią się zależności pomiędzy podmiotami komunikacji, aktami komunikacji, treściami komunikowanymi a aksjosfera moralna współczesnej kultury.

Trzy zjawiska z zakresu istnienia, realizacji i oddziaływania wartości moralnych mogą być obiektem badań etycznych w komunikacji językowej:

- dostrzeganie wartości moralnych;

- operowanie ideami moralnymi, normami i ocenami;

- uzasadnianie potrzeb samoprzymuszenia (samosterowności ludzkiej) w zakresie realizacji dobra moralnego w procesie komunikowania.

Do rozstrzygania w etyce komunikacji językowej pozostają następujące kwestie:

- jakie funkcje spełnia etyka komunikacji?

- jak komunikować etycznie (w zgodzie z dobrem moralnym)?

- jakie odmiany dobra moralnego przejawiają się w komunikacji językowej?

- jakie kierunki filozoficzno-etyczne kształtuja postawy, wybory, motywy moralne, obyczajowość moralną, normy, oceny i wartości moralne, sankcje moralne, odpowiedzialność moralną w komunikowaniu?

- jak moralnie postępować w sytuacjach komunikacyjnych?

- jakimi normami moralnymi, wzorcami etycznymi kierować się w komunikowaniu?

- jakie uznać autorytety w dziedzinie moralności komunikowania? 
- co radzić innym w zakresie moralności komunikowania?

- jak oceniać własne i cudze postawy moralne w komunikowaniu?

- czy kierować się kryteriami moralnymi wypracowanymi w przeszłości przez daną zbiorowość?

- które obyczaje komunikacyjne kultywować, a które kontestować w imię dobra ogółu oraz poszanowania godności i dobra indywidualnego?

- jakich szukać uniwersalnych argumentów moralnych?

- w jaki sposób z pozycji lidera społecznego, przywódcy, pedagoga, wychowawcy etc. pomóc ludziom w ich indywidualnym uporządkowaniu światopoglądu w dziedzinie moralnego postępowania komunikacyjnego?

- jakie przyjać kryteria oceny komunikowania pod względem realizacji dobra moralnego lub zła moralnego?

- jakie normy i wymogi moralności respektować w sytuacjach komunikacyjnych?

- w jaki sposób przy naukowym opisie i ocenie moralnej komunikowania zachować rygor metodologiczny, aby unikać nienaukowego wywierania presji, wyzbyć się stylistyki propagandy, stylistyki wychowania?

- jaką przyjąć aksjologiczną definicję wartości moralnej w komunikacji językowej?

- jaką przyjąć typologię wartości dodatnich moralnie w komunikowaniu (opatrywanych pozytywnymi ocenami aksjologicznymi; tego, co ludzie cenią; tego, co jest przedmiotem pragnień, celem dążeń), a jaką typologię antywartości (wartości negatywnych, tj. tego, co jest aksjologicznie oceniane negatywnie)? (na temat rozróżnienia pojęć „wartości dodatnie”, „wartości ujemne", czyli znaku własności wartości in plus oraz in minus - zob. Elzenberg 2002, 171; Elzenberg 2005, 186; Ostasz 2009, 21-22, 151. W niektórych kręgach filologów aksjologiczny termin 'wartość dodatnia' bywa kwalifikowany jako pleonazm, zaś termin 'wartość ujemna' jako oksymoron).

- jakie wartości moralne są realizowane, wcielane w komunikacji językowej?

- jakie antywartości mają wpływ na komunikację językową?

- jakie moralne wartości komunikowania zaliczyć do autotelicznych (cennych ze względu na nie same), a jakie do wartości wtórnych (cennych z uwagi na odniesienia do czegoś innego)?

- jakie są sposoby odnoszenia się podmiotów komunikowania językowego do obiektów cenionych?

- jakie oceny moralne cudzych uczynków identyfikują członków danej zbiorowości (wspólnoty komunikacyjnej)?

- jakie wartości cudze (cudze stany doświadczane / oceniane przez współczucie lub wczuwanie się, empatię) przejawiają się w komunikacji językowej? 
- jakie oceny moralne nabierają cech stereotypu w komunikowaniu językowym?

- jaki jest stopień świadomości i wrażliwości moralnej w danych komunikujących się grupach społecznych?

- jakie wartości rozpoznawane są poprzez ocenianie w komunikowaniu językowym?

- jaka jest hierarchia wartości moralnych w danych wspólnotach komunikacyjnych?

- co jest uznawane w danej wspólnocie komunikacyjnej za największe dobro moralne?

- jakie intencje czynów poszczególnych uczestników komunikacji językowej są przyczyną dobrych lub złych relacji międzyludzkich?

- jakie konflikty moralne ujawniają się w komunikacji językowej?

- jakie cenne moralnie postawy manifestują się w komunikowaniu?

- jakie są podstawowe zasady dobrego postępowania w komunikowaniu?

- jaka jest zależność pomiędzy pojęciami moralnymi (np. odpowiedzialność moralna, godność, honor, szczęście, sumienie, dobroć, sprawiedliwość, równość, tolerancja, szacunek, uznanie, współczucie, anomia) a postawami moralnymi w komunikowaniu (np. postawa szacunku, postawa sprawiedliwości, postawa altruizmu, postawa dobroci, życzliwości, opieki, ofiarności, postawa wierności, postawa współczucia, postawa anomiczna)?

- jakie moralne normy i reguły (powinności moralne) są (względnie powinny być) upowszechniane w etyce komunikacji językowej?

- jaki katalog obowiązków moralnych formułuje się na gruncie moralistyki względem uczestników komunikacji?

- jakie są moralne aspekty zastosowania funkcji impresywnej w komunikacji językowej?

Na poziomie lingwistycznym (również i psychologicznym) wybór podmiotów komunikujących (zwłaszcza nadawców) pomiędzy etycznym i nieetycznym sposobem komunikowania sprowadza się do wyboru moralnego między perswazją a manipulacją (Dudziak 2012, 33-34; Dudziak 2014, 169-183; Badyda 2012, 177178). Uzasadnione wątpliwości etyczne badaczy komunikacji perswazyjnej budzą te wszystkie przejawy perswazji, w których korzysta się ze środków dodatkowych, a nie wyłącznie z przejrzystej racjonalnej argumentacji (Dudziak 2012, 17). Jak w tym kontekście skonstatowała Ewa Badyda:

można by uznać, że etycznym sposobem uzyskania wpływu na odbiorcę jest przekonywanie go ograniczone do argumentacji logicznej, która pozwoli mu uzmysłowić sobie odpowiednie fakty i związki pomiędzy nimi, a następnie samo- 
dzielnie wydać właściwy sąd, ale wymaga to po pierwsze założenia, że wyznaje on te same wartości i ma te same interesy co nadawca, po drugie zaś - że zachowania i postawy człowieka opierają się jedynie na czynnikach racjonalnych i nie mają związku ze sferą emotywno-wolicjonalną. Ponadto nawet jeśli przyjmiemy, że intencje nadawcy wypowiedzi są czyste i szlachetne w sytuację aktu przekonywania uwikłane jest ryzyko związane z oceną przedstawianej sytuacji, dokonywaną przez nadawcę (Badyda 2012, 176).

Interesującą kwestią pozostaje pytanie: czy jest możliwa perswazja z natury neutralna pod względem etycznym? Odpowiedź prowadzić może do konkluzji, że każdy akt komunikacyjny nie jest $w$ istocie neutralny etycznie ze względu na nacechowanie aksjologiczne, obecne w nim elementy wartościowania (Skibiński 2009, 84-92; Badyda 2012, 176).

Etyka komunikacji językowej nabiera szczególnego znaczenia w aspekcie efektywności komunikacyjnej (O’Keefe 1990, 17). Osiąganiu tej kategorii służy świadome dostosowanie się w komunikacji do zaleceń ujętych w postaci zasad kooperacji Herberta Paula Grice'a (maksym lingwistycznych): prawdziwości, informacyjności, merytoryczności, organizacji. Przejawem dbałości o etykę komunikowania będzie także respektowanie reguł retorycznych Geofreya Leecha, dotyczących właściwych sposobów organizacji tekstu oraz odpowiednich wzajemnych relacji uczestników aktu komunikowania (Dudziak 2012, 44-46; Kozłowska 2018, 49-59).

Przejawem nieetycznej komunikacji językowej (inaczej: braku etyki komunikacyjnej, ignorancji dla wartości moralnych w komunikowaniu) będzie współczesna recepcja erystyki Artura Schopenhauera. Każde zastosowanie w aktach komunikacji schopenhauerowskich sposobów erystycznych będzie naruszeniem etycznych reguł dialogiczności, kooperacji językowej. Należy zauważyć, że schopenhauerowska dialektyka erystyczna została przewidziana dla szczególnego rodzaju relacji międzyludzkich: pozbawionych zaufania, nacechowanych wrogością aktów sporu (kłótni, polemiki etc.). W komunikowaniu erystycznym uczestnikom sporu nie zależy na porozumieniu, lecz wyłącznie na zdyskredytowaniu oponenta. Koncepcja antropologii filozoficznej Schopenhauera wynikła z deterministyczno-pesymistycznych przesłanek, ujętych w sentencji: „człowiek jest zły z natury" (Schopenhauer 1986, 30). Dialektykę erystyczną Schopenhauera cechowały ponadto: przekonanie o złym charakterze człowieka; brak wiary w możliwości ludzkiego rozwoju intelektualnego i moralnego; traktowanie komunikacji, dyskutowania w kategoriach agonalnych, jako walki, sporu; uznawanie rozmówcy za wroga, którego należy pokonać, lekceważąc prawdę, obiektywną słuszność (Schopenhauer 1986, 9-10, 12). Erystyka jest sofistycznym sposobem dyskutowania, lekceważeniem kategorii obiektywnej prawdy, 
dążeniem do zachowania pozorów racji w rezultacie wykorzystywania nieprawdziwych twierdzeń i błędnych wniosków (Schopenhauer 1986, 27-29). Charakterystyczne pod tym względem jest jedno z zaleceń Schopenhauera: „Nie należy przyjmować nawet słusznych przesłanek, jeżeli przewiduje się niedogodne dla nas konsekwencje" (Schopenhauer 1986, 67).

\section{BIBLIOGRAFIA}

\section{ŹRÓDŁA}

Elzenberg H.: (2001), Rzeczywista podstawa etyki, w: Pisma etyczne, oprac. i wstęp L. Hostyński, Lublin: Wydawnictwo UMCS.

Elzenberg H.: (2002), Wartość ujemna, w: Pisma aksjologiczne, oprac. L. Hostyński, Lublin: Wydawnictwo UMCS.

ELZENBERG H.: (2005), O różnicy między „pięknem” a „dobrem”, w: Wartość i człowiek. Rozprawy z humanistyki i filozofii, wyd. II oprac. i wstęp W. Tyburski i R. Wiśniewski, Toruń: Wydawnictwo UMK.

Elzenberg H.: (2005), Przeciw hedonizmowi, w: Wartość i człowiek. Rozprawy z humanistyki i filozofii, oprac. i wstęp W. Tyburski i R. Wiśniewski, wyd. II, Toruń: Wydawnictwo UMK.

\section{PRACE CYTOWANE}

BADYDA E.: (2012), Odpowiedzialność za słowo w świetle współczesnego wykorzystywania języka w funkcji perswazyjnej, „Ethos” 25, nr 1-2 (97-98).

CegieŁa A., Kuciński P., Polkowska L., STĘPIEŃ M.: (2014), Studia z etyki słowa, Warszawa: Dom Wydawniczy Elipsa.

DUDZIAK A.: (2012), Informacyjne i perswazyjne funkcje reklamy społecznej w świetle antropologii i aksjologii, Olsztyn: UWM.

DUDZIAK A.: (2014), O funkcjonalnym dyskursie lingwistycznym na temat perswazji i manipulacji, „Zeszyty Naukowe” XXVIII (Ostrołęckie Towarzystwo Naukowe im. Adama Chętnika), Ostrołęka.

DUDZIAK A.: (2015), Kryzys wartości na przykładzie PR-owskiej analizy dyskursu polskiej debaty publicznej, w: Człowiek w obliczu kryzysu. Kryzys w perspektywie interdyscyplinarnej, red. A. Chyczewska, I.M. Kijowska, Elbląg: Wydawnictwo PWSZ.

DZIAMSKI S.: (1997), Aksjologia. Wstęp do filozofii wartości, Poznań: Wydawnictwo Naukowe Instytutu Filozofii UAM.

DZIAMSKI S.: (2002), O świadomości aksjologicznej podmiotu. Studium krytyki pozytywnej, Poznań: Wydawnictwo Naukowe Instytutu Filozofii UMK.

GRICE H.P.: (1980), Logika i konwersacja, w: Język w świetle nauki, praca zbiorowa, tłum. zbiorowe, wstęp B. Stanosz, Warszawa: Czytelnik.

HABERMAS J.: (1972), Toward a Theory of Communicative Competence, „Recent Sociology”, nr 2.

HABERMAS J.: (1986), Pojęcie działania komunikacyjnego (uwagi wyjaśniające), przekł. A.M. Kaniowski, „Kultura i Społeczeństwo”, nr 3. 
HABERmas J.: (1999), Teoria działania komunikacyjnego, t. 1: Racjonalność działania a racjonalność społeczna, przekł. A.M. Kaniowski, Warszawa: PWN.

HABERMAS J.: (2002), Teoria działania komunikacyjnego, t. 2: Przyczynek do krytyki rozumu racjonalnego, przekł. A.M. Kaniowski, Warszawa: PWN.

HoSTYŃSKI L.: (1991), O wartościach. Aksjologia formalna, estetyka i etyka Henryka Elzenberga, Lublin: Wydawnictwo UMCS.

JAROŃ J.: (1995), Z etyką na ty. Od egipskiego Ptahhotepa do Karola Wojtyły, Łódź: Dajas.

JAŚTAL J.: (2012), Retoryka jako etyka praktyczna. O pewnej interpretacji Retoryki Arystotelesa, „Ethos” 25, nr 1-2 (97-98).

KAMIŃSKI S.: (1989), Jak filozofować? Studia z metodologii filozofii klasycznej, Lublin: Towarzystwo Naukowe Katolickiego Uniwersytetu Lubelskiego.

Kowalski S., TUlLi M.: (2003), Zamiast procesu. Raport o mowie nienawiści, Warszawa: Wydawnictwo W.A.B.

KoZŁOWSKA A.: (2018), Etyczny wymiar komunikacji literackiej w perspektywie językoznawstwa, w: Ku rzeczom niebłahym, red. J. Chojak, Z. Zaron, Warszawa: BEL Studio.

LICHAŃSKI J.Z.: (2009), Etyczne korzenie retoryki, w: Retoryka i etyka, red. B. Sobczak, H. Zgółkowa, Poznań: Wydawnictwo Poznańskie.

ŁODZIŃSKI S.: (2003), Problemy dyskryminacji osób należących do mniejszości narodowych i etnicznych w Polsce, raport nr 219, Wydział Analiz Ekonomicznych i Społecznych Kancelarii Sejmu, Biuro Studiów i Ekspertyz, Warszawa.

MCCARThy T.: (1978), The Critical Theory of Jürgen Habermas, Cambridge, Mass., London: MIT Press.

O’KeEfe D.: (1990), Persuasion: Theory and Research, London: Sage Publications.

Ostasz L.: (2009), Czym są wartości? Zarys aksjologii, Olsztyn: UWM.

SCHOPENHAUER A.: (1986), Erystyka, czyli sztuka prowadzenia sporów, wyd. 4, Warszawa.

SKIBIŃSKI A.: (2009), Perswazja etycznie neutralna? Od retoryki do meta-NLP, w: Retoryka i etyka, red. B. Sobczak, H. Zgółkowa, Poznań: Wydawnictwo Poznańskie.

STYCZEŃ T.: (1984), W drodze do etyki, Lublin: RW KUL.

TYBURSKI W.: (2006), Myśli i ludzie. Elzenberg, Warszawa: Wiedza Powszechna.

WEBER A.: (2009), Manual on hate speech, Strasbourg: Council of Europe.

WEBER M.: (2004), Wolność od wartościowania - jej sens w naukach socjologicznych i ekonomicznych, w: Racjonalność, władza, odczarowanie, tłum. M. Holona, Poznań: Wydawnictwo Poznańskie.

\title{
WOKÓŁ PODSTAWOWYCH ZAGADNIEŃ METODOLOGICZNYCH I PROPOZYCJI BADAWCZYCH W ZAKRESIE ETYKI KOMUNIKACJI JEZZYKOWEJ
}

\author{
St re s z c z e n i e
}

Artykuł ma charakter teoretyczno-badawczy. Zawiera propozycje badań nad podstawowymi kwestiami etyki komunikowania językowego. Potrzebę rozwoju etyki komunikacji językowej uzasadniają dwa zjawiska: szerzenie się mowy nienawiści, kryzys wartości w debacie publicznej. Opracowanie jest głosem w dyskusji o tym, w jaki sposób badać etykę komunikacji języ- 
kowej. Prezentowane refleksje są inspirowane pracami takich etyków, jak: Henryk Elzenberg, Stanisław Kamiński, Andrzej Grzegorczyk i Józef Jaroń.

Słowa kluczowe: komunikacja językowa; etyka; etyka komunikacji językowej.

\section{BASIC METHODOLOGICAL ISSUES AND RESEARCH PROPOSALSOF LANGUAGE COMMUNICATION ETHICS}

\section{$\mathrm{S} \mathrm{u} \mathrm{m} \mathrm{m} \mathrm{a} \mathrm{r} \mathrm{y}$}

The article has a theoretical and research character. It contains proposals for research on the basic issues of language communication ethics. The need to develop the ethics of linguistic communication is justified by two phenomena: the spread of hate speech, the crisis of values in the public debate. The study is a voice in the discussion on how to study the ethics of linguistic communication. The presented reflections are inspired by the work of such ethicists as Henryk Elzenberg, Stanisław Kamiński, Andrzej Grzegorczyk and Józef Jaroń.

Key words: language communication; ethics; ethics of language communication. 